\title{
コンクリート床直仕上げ作業用ロボットの開発に関する 基礎的研究 \\ THE FUNDAMENTAL RESEARCH FOR THE DEVELOPMENT OF CONCRETE FLOOR SLAB FINISHING ROBOT
}

\author{
新井一彦 \\ Kazuhiko ARAI
}

\begin{abstract}
This paper describes preliminary surveys and fundamental experiments for the development of concrete floor slab finishing robot.

The auther discusses the unique development procedure and notes the importance of setting proper development target. An analysis of working hours is presented as an example of one such survey, together with details on robot task allocation and function setting. Data for robot design was obtained from experiments on the selection of finishing tools suitable for robot, and on the dimensions and weight of locomotion equipment capable of traveling over green concrete.
\end{abstract}

Key words； コンクリート、床仕上げ、ロボット、開発プロセス、基礎実験、 仕上げツール、移動装置 concrete, floor slab finishing, robot, development procedure, fundamental experiment, finishing tool, locomotion equipment

\section{1. 序 論}

建築生産の合理化の一手段として、近年建築用ロボッ トの研究開発が進められるようになってきた。建築分野 へのロボットの導入に当たっては様々な制約条件があり。 しかも新規にロボットを開発しなければならないことが 多く、製造業におけるロボットの導入方法とは異なった アプローチの必要性があるとされている。12)

新たにロボットを開発するに当たっては、ロボット化 対象作業の選定、期待される効果の評価などと同時に、 対象とする作業の実態や制約条件などについての基礎的 な調查を行い、開発目標ならびに要求機能を的確に把握 することが必要である。仕上がり精度などの品質に深く 係わる作業を対象する場合には、ロボットに適合した作 業ツールの開発が、また、建築工事においてはロボット の移動性に関する検討が特に重要であり、移動装置の設 計に当たって技術的に未解决な部分の調查・実験が不可 欠である。
以上の観点から、ロボットの開発目標や要永機能を明 らかにするための調查や休面の仕上がり精度の確保を可 能とする仕上げツールの選定実験、移動装置の設計のた めの実験など、ロボットの開発に至る事前の検討を本研 究の範囲とした。

なお既往の研究として、コンクリート休直仕上げロボ ットの開発に関する報告3) 4) もあるが、それらは開発事 例の紹介が主体で、基礎的実験の記述は走行装置部の特 定の部分で若干触れられている程度に止まっている。一 方、近年では大学において仕上げッールに焦点を当てた 機械ごての仕様の影響に関する基礎的考察や左官用回転

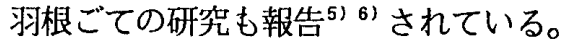

\section{2. 建築用ロボットの開発プロセスと検討課題}

建築用ロボットは、製造業での導入のように既に市販 されているロボットを選定して使用するという状況には 
なく、建築作業の使用目的に合わせた新しいロボットを 開発しなければならない場合がほとんどである。そのた 认、建築用口ボットの開発に当たっては、テーマの設定 から害用化に至るまでのプロセスを十分に検討し、実用 的なものを効率良く開発する手段を講ずることが重要と なる。筆者は、ロボットの開発プロセスと検討課題につ いて予めその内容を吟味して、表-1 ${ }^{n}$ に示す開発の進 め方を創案した。開発プロセスを 7つのPhaseに分類し、 各Phaseごとにその段階での検討課題を逐次検討しなが ら開発を進めることとした。

本論文は、Phase 1 においてコンクリート床直仕上

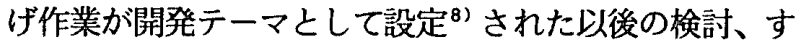
なわち、Phase 2 及びPhase 3 の範囲に関して行っ た調査・実験を対象とする。

Phase 2では、開発すべきロボットの開発目標を設定 するために a.〜 g. に関する検討のうち、a. 対象作業 工程の調查・分析、c. 仕上がり精度の目標值の設定につ いて本論文では示した。

Phase 3では、ロボットの基本設計を行うに当たり、 a.〜 e.に関する検討のうち、d. 仕上げッールの選定 ならびに移動装置の設計デー夕収集のために行った機能 要素の開発。実験について本論文では示した。

なお、この開発プロにこにに従って開発を進めたコンク リート床直仕上げロボットは現在、市販の段階に至って いる。

3．コンクリート床直仕上げ作慈に関する実態調查

3. 1 作業工程に関する調査

コンクリート床直仕上げ（以下、床直仕上げと呼ぶ） における作業工程の実態把挃ならびにロボット化の対象
範囲を確認することを目的として調査を行った。

（1）調查方法

工事現場において床直仕上げ作業を直接観察すると共 に作業者からのヒアリング調查により作業工程を調査し た。

\section{（2）調査結果及び考察}

床直仕上げ作業工程は近年、トロウェル（動力ごて、 パワーフィニッシャとも呼ばれる、以下、トロウェルと 呼ぶ）を用いた方法が一般的になりつつあり、その作業 工程は図ー1のようであった。この場合、トロウェルで は仕上げられない床スラブ周辺や壁際などの付近は従来

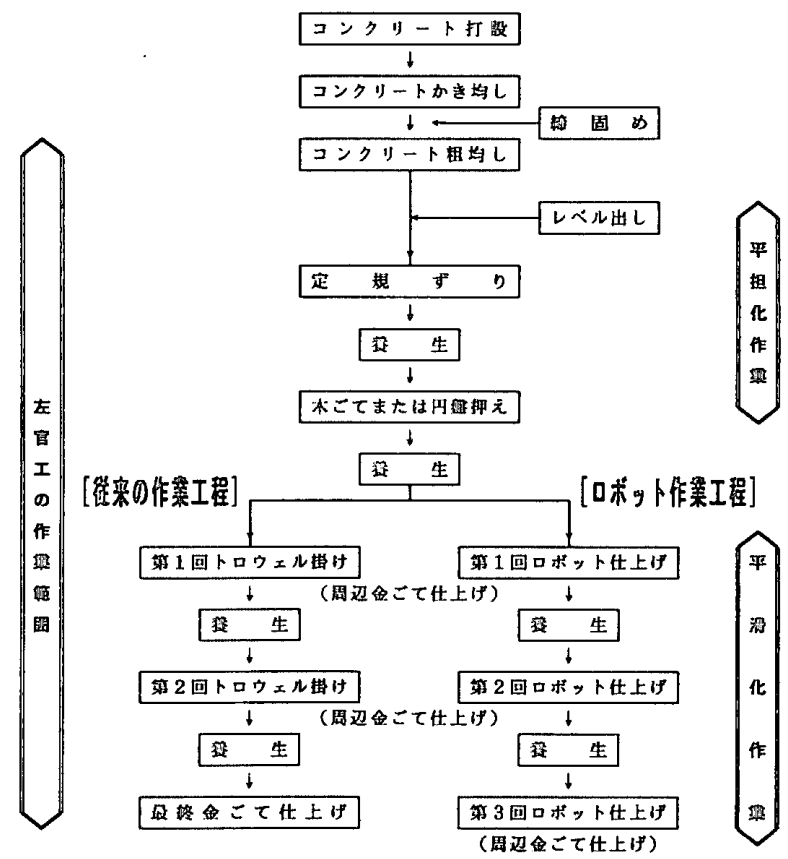

図ー1 コンクリート床直仕上げの作業工程

表ー 1 建築用ロボットの開発プロセスと検討課題

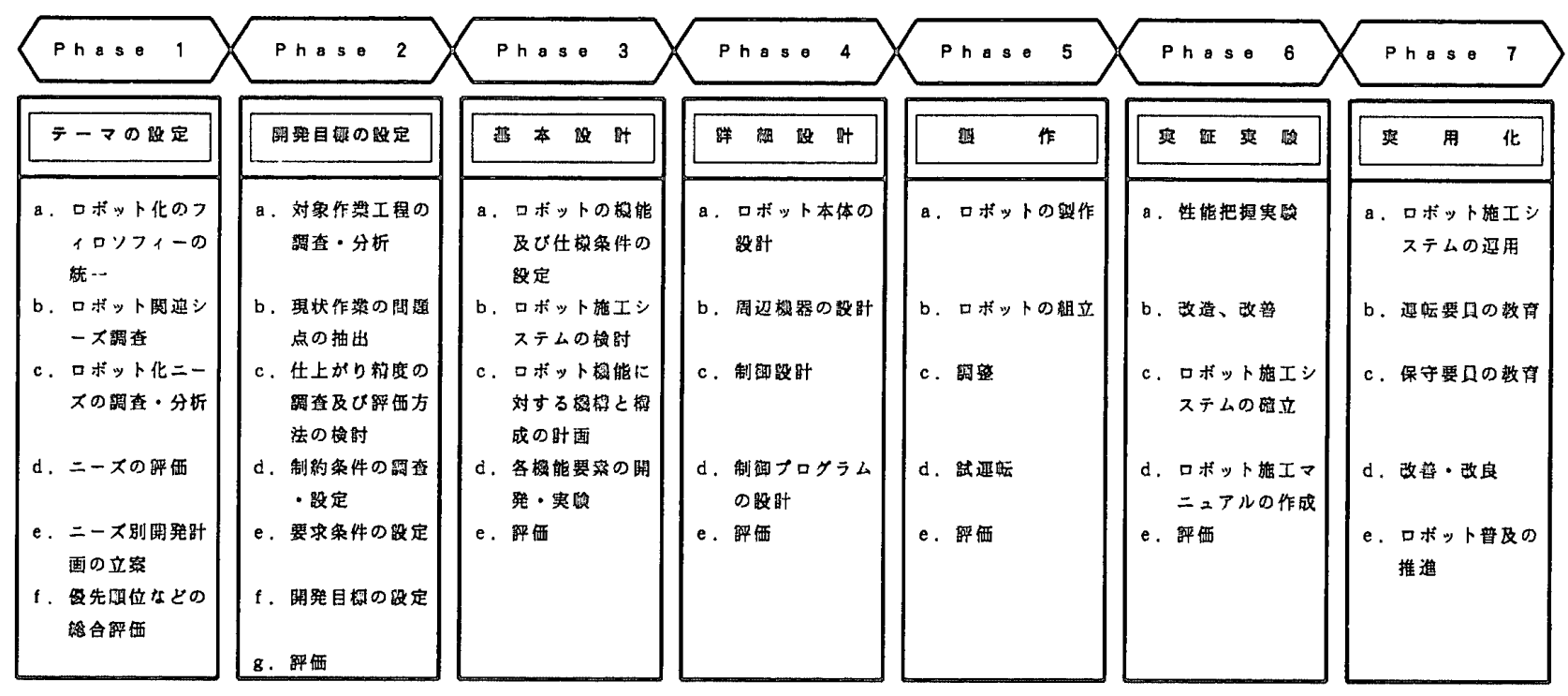


と同様に作業者が金ごてにより仕上げ作業を行っている。 通常、左官専門工事業が請負う作業範囲は、コンクリ 一ト粗均しから最終の金ごて仕上げ作業工程までとなっ ており、このうち、コンクリート粗均しから定規ずり、 木ごて仕上げ作業まではコンクリート床表面の平坦化の 作業であり、それ以降は床面の平滑化作業となる。

床直仕上げロボットは、前述した作業の後半部分を作 業範囲とするものであり、コンクリート床表面の表面粗 さを細かくするための平滑化作業を行う。床直仕上げロ ボットによる作業工程は図ー1に示したようにトロウェ ルによる作業工程をロボットに代替することとなる。

3. 2 作業時間の測定

左官工の床直仕上げ作業における作業時間の実態を把 握し、ロボットが分担する作業時間の割合の推定ならび にロボットの要求機能の設定の留意事項を検討すること を目的として作業時間の測定を行った。

\section{（1） 测定方法}

5 分間隔のワークサンプリング方法により、作業者が 行っている作業内容を記録した。測定対象とした左官工

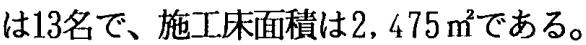

\section{(2) 測定結果及び考察}

作業内容別による作業時間（養生の待機時間、測定視 野外で測定不能などの時間を除く）の構成此率を図 -2 に示す。ここで、養生に必要な待機時間を除いた理由と しては、温度・湿度、風などの環境条件ならびにコンク リートの調合などの諸条件によりコンクリートの硬化度 合いは大きく変動するが、このインターバルは今回の口 ボットの開発に関して特別影響を及ぼすものではないか らである。一方、仕上げに要する正味作業時間はコンク リートの硬化状態が見合っていれば仕上げ作業時間自体 は諸条件に対して大きな变動がないと考えられ、この作 業洔間を分析の対象とした。

左官工の作業を平坦化作業と平滑化作業に分類して作

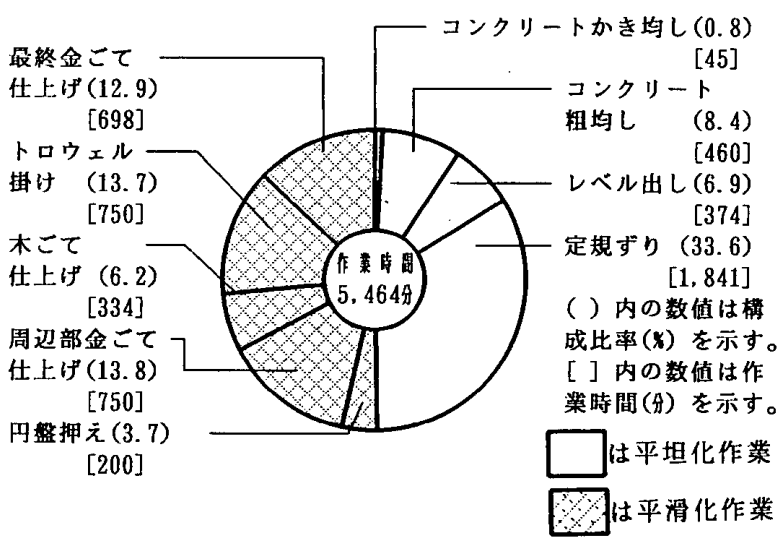

図ー2 コンクリート床直仕上げ作業の作業時間の構成
業時間の構成此率を算出すると、前者が53.4\%、後者が 46.68であり、ほぼ同様の比率であることが分かった。 平滑化作業における木ごて仕上げ、トロウェル掛け、最 終金ごて仕上げの合計作業時間は、全作業時間の $32.8 \%$ を占めている。また、トロウェルが入り込めないスラブ 周辺部の金ごて仕上げの割合は $13.8 \%$ と此較的大きな比 率を示している。

この測定結果から、床スラブ周辺部の金ごて仕上げを 除くと、左官工の全作業時間のおよそ 3 分の 1 の作業を また、平滑化作業時間のおよそ 3 分の 2 の作業をロボッ トが分担することになることが分かった。ロボットの作 業分担割合をさらに高めるためには、床スラブ周辺部な どへ接近可能で小回りがきく方法を考案する必要がある。

\section{4. 直仕上げ床面の仕上がり精度の許容值設定に関する 実験}

ロボットで直仕上げを行う場合には仕上がった床面を 客観的に評価する必要がある。しかしながら、JASS 5 ならびに一般の建築工事の仕様書にはコンクリート床面 の仕上がり精度として、表面粗さや段差などに関する定 量的な仕様は見受けられない。そのため本実験ではコン クリート下地として求められる直仕上げ休面の表面粗さ、 段差に注目して、それらに関する独自の許容値を設定す ることを目的とした。本実験では、床仕上げ材料として は塩化ビニル床タイル（以下、Pタイルと呼ぶ）を想定 した。

\section{（1） 実験項目}

実験は次に示す 3 項目について行った。

(1) キャスター試験によるPタイル目地幅の広がり

(2) キャスター試験によるPタイルのひび割れ状況

(3) キャスター試験後のPタイルの接着強度

\section{（2）実験方法}

試験に用いた供試体の寸法は、 $400 \times 400 \times 40 \mathrm{~mm}$ のコ ンクリート板で、その表面は所定の表面粗さ（ここでは 表面粗さの表示方法として最大高さを用い、測定長さ 30 cmにおける凹凸の最大の差を言う。以下、表面粗さと呼

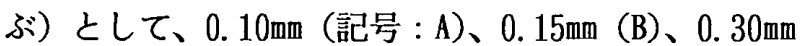
(C)の 3 水準、また、段差は $0.3 \mathrm{~mm}$ (D)、0. $0 \mathrm{~mm}$ (E)、 $0.8 \mathrm{~mm}$ (F)の 3 水準の供試体を製作し、2 週間空中養生 した。なお、供試体の表面状態は不陸測定器9)により確 認した。その後、Pタイル $(300 \times 300 \mathrm{~mm})$ を 4 分割し、一 般に使用されているSBR合成ゴム系接着剤により供試体 に接着し試験体とした。試験体数は各々 2 体とした。

P タイルの目地幅の広がり及びひび割れ状況に関する 実験は、林材料試験方法のキャスター試験装置 ${ }^{101}$ を用 いて、キャスター部に $60 \mathrm{Kg}$ の荷重をかけ、Lissajou曲線 に近似した 8 の字型の図形の軌趾を試験体に与えた。試 
験回数は連続で100回とした。なお、キャスター試験

（以下、Ca試験と呼ぶ）は、Pタイルを接着後14日目に 行った。また、Ca試験後、Pタイルの目地幅の広がり及 び表面のひび割れ状況について目視により観察した。

接着強度試験はCa試験後、Pタイルがキャスターと接 触した部分（以下、Ca試験内と呼ぶ、記号：A〜F) と非 接触部分 (以下、Ca試験外と呼ぶ、記号 : $A^{-} \sim F^{\prime}$ ) につ いて行った。接着試験体の寸法はCa試験での供試体の寸 法の関係から $27 \times 27 \mathrm{~mm}$ とし、建研式引張試験機を用いて 行った。試験は、Ca試験後 3 日目に行い、試験体数は各 々 4 体とした。

\section{(3) 実験結果及び考察}

(a) Pタイル目地幅の広がり

Ca試験後のPタイル目地幅の広がりの状況 ${ }^{11}$ 文図一 3 に示す。表面粗さ $\mathrm{A}$ 試験体の $\mathrm{P}$ タイル目地幅の広がり の平均は $1.13 \mathrm{~mm}$ 、同様に表面粗さ B 試験体は $1.39 \mathrm{~mm}$ 、 表面粗さC試験体は1.69mであった。この結果、Pタイ ル目地幅の広がりは表面粗さが粗くなるほど大きくなる 傾向を示した。

また、段差については段差 D 試験体のP タイル目地幅 の広がりは1.50mm、同様に段差 $\mathrm{E}$ 試験体では2. 03m 、段 差F試験体は2.45mmであった。この結果から、段差が大 になるほどCa試験後のP タイル目地幅の広がりは大きく なる傾向か認められた。

(b) Pタイルのひび割れ

Ca試験後のP タイルのひび割れは、いずれの表面阻さ 試験体にもひび割れは認められなかった。しかし、段差 試験体の場合は、段差 D試験体はキャスターとの摩擦に より Pタイルに含有している炭酸カルシウムが P タイル 表面に抽出し、白色化する現象が認められたが、ひび割 れは生じていない。段差 $\mathrm{E}$ 試験体は段差部に沿ってP夕 イルに部分的なひび割れが生じた。また、段差F試験体 では段差部に沿ってPタイルは全面的にひび割れが認め られた。

この結果、Ca試験後のPタイルのひび割れは、表面粗 さにはあまり影響されず、段差が大きいほど影響は大に なる傾向を示した。

(c) Pタイルの接着強度試験結果

Ca試験後のP タイルの接着強度の試験結果 11 をを図一 4 に示す。

Ca試験内での表面粗さA 試験体におけるPタイルの接 着強度の平均は $2.33 \mathrm{Kgf} / \mathrm{cm}^{2}$ で、同様に表面粗さ B 試験体 では2.00 Kgf $/ \mathrm{cm}^{2}$ 、表面粗さ C試験体では $1.13 \mathrm{Kgf} / \mathrm{cm}^{2}$ 之表 面粗さが粗くなるに従い接着強度は小さくなる傾向が認 められた。一方、Ca試験外の試験体では表面粗さによる 差異は判然としていない。

Ca試験内での段差試験体では段差の小さい方が若干大 きな接着強度を示しているが、それほど大きな差は認め
られなかった。また、Ca試験外の段差試験体も段差の大 きさによる差異は判然としていない。

また、表面粗さ試験体ならびに段差試験体ともCa試験 内の方がCa試験外より、いずれも大きな接着強度を示し た。Ca試験内の試験体は、60Kgの荷重を受けており圧密 の効果によるものと考えられる。また、全体的に今回の 試験における接着強度は低めの值であったが、これは養 生期間が短かったこと、Ca試験によってPタイルが移動 し接着層に影響を与えたことが一因と考えられる。

以上の実験結果を踏まえて、今回のロボット開発に当 たっての開発目標として、床面の表面粗さは最大高さの 表示で $0.1 \mathrm{~mm}$ 以下、段差は $0.3 \mathrm{~mm}$ 以下を仕上がり精度の 目標値とすることとした。床面の仕上がり精度に関する 設定値を普遍化するには今後さらに多くの実験結果を得 る必要がある。

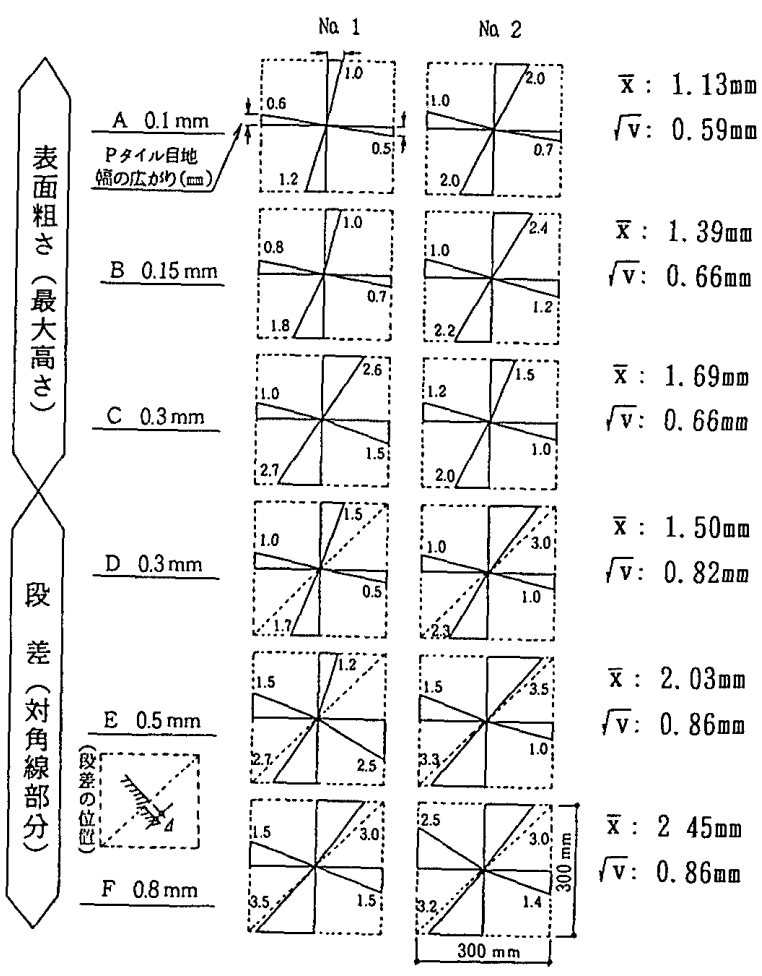

図ー3キャスター試験後のPタイル目地幅の広がり

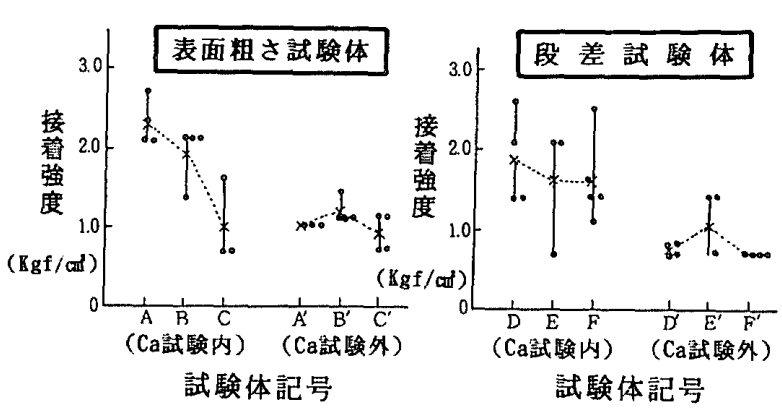

図一 キャスター試験後の $\mathrm{P}$ タイルの接着強度の比較 


\section{5.ロボットの移動装置の設計に必要なデータを得るた めの実験}

5. 1 ロボットの移動装置に加わる荷重とコンクリー トの沈みに関する実験

本実験は、コンクリートを休に打設して間もない初期 状態においてロボットが移動する際に、コンクリート表 面が沈み走行障害を起こしたり、床面の仕上がり性状に 対する影響を検討すると同時にロボットの移動機構に必 要な設計上のデータを得ることを目的として行った。

\section{（1）実験項目}

ロボットの移動装置としてローラーを使用することを 前提として、コンクリートの床表面上を走行させたとき のコンクリート表面の沈み量（以下、沈み量と呼ぶ）を 主な実験項目とし、同時にコンクリートの圧縮強度なら びに内部温度を測定した。

\section{（2）実験方法}

長さ $100 \mathrm{~cm} 、$ 幅 $70 \mathrm{~cm} 、$ 厚さ $10 \mathrm{~cm}$ の試験体のコンクリー 卜表面上を 1 時間毎にローラーを走行させ沈み量を測定 した。使用したローラーは径 $30 \mathrm{~cm}$ 、長さ $30 \mathrm{~cm}$ 、質量は $30 \mathrm{Kg}$ 及び $60 \mathrm{Kg} の 2$ 種類で材料は鋼管を使用した。沈みの 測定は試験体の両脇にマグネットスタンドを配置し、そ こにピアノ線をローラーの高さに合わせて張り、ローラ 一をコンクリート.上で走行させ、ローラーの最高部とピ アノ線との隙間を厚さゲージで測定し、その值を沈み量 とした。同時にコンクリートの圧縮強度 $(\$ 10 \times 20 \mathrm{~cm}$ モー ルド）をコンクリート打設後 4、5、6、7 時間にCBR 試験機により測定した。実験は、温度 $20^{\circ} \mathrm{C} 、$ 湿度 $80 \% の$ 室内で行い、コンクリート及び養生温度を自動記録した。 コンクリートの調合は床面に打設されるコンクリートの 施工事例の調查結果から、普通コンクリート、設計基準

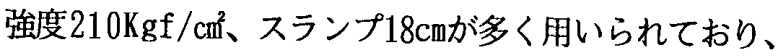
この結果を踏まえて表ー 2 に示す計画調合とした。

\section{(3) 実験結果及び考察}

積算温度 ${ }^{12)}$ (以下、 $\mathrm{T}^{0} \mathrm{~T}$ と呼ぶ ) とローラーの走行 による沈み量との関係を示すと図ー 5 及び $6^{13)}$ のとお りである。

両者の関係は指数曲線を示し、ローラー質量が $30 \mathrm{Kg} の$ 之きの沈み量は、 $25 \mathrm{~T}^{\circ} \mathrm{T}$ で10mm前後、 $60 \mathrm{~T}^{\circ} \mathrm{T}$ で $5 \mathrm{~mm}$ 前後、 $100 \mathrm{~T}^{0} \mathrm{~T}$ で2mm前後となり、1 $140 \mathrm{~T}^{\circ} \mathrm{T}$ でほぼ $0 \mathrm{~mm}$ となっ た。また、ローラー質量が60Kgのときの沈み量は、70 $\mathrm{T}^{0} \mathrm{~T}$ で5mm 前後 $100 \mathrm{~T}^{\circ} \mathrm{T}$ で3mm 前後、140 $\mathrm{T}^{\circ} \mathrm{T}$ でほぼ $0 \mathrm{~mm}$ となった。ちなみに、140 To Tのときのコンクリー

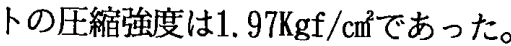

$$
\text { ローラーの走行によるコンクリート表面の障害につい }
$$

て観察した結果を示すと、ローラー質量が30Kgの場合、 $100 \mathrm{~T}^{0} \mathrm{~T}$ で、また、60Kgの場合80 $\mathrm{T}^{\circ} \mathrm{T}$ で、ローラーにセ メントペーストが部分的に付着し、コンクリート表面を 乱す現象が見られた。この現象を回避するための方策に
表ー2 コンクリートの計画調合

\begin{tabular}{|c|c|c|c|c|c|c|c|}
\hline $\begin{array}{r}\text { 設計王 } \\
\text { ( } \mathrm{Kg} \\
\end{array}$ & $\begin{array}{l}\text { 隻強度 } \\
\left.\mathrm{f} / \mathrm{cm}^{2}\right)\end{array}$ & \multicolumn{2}{|c|}{ 水さメント比 } & \multicolumn{2}{|c|}{ スランプ } & 納骨材率 & 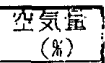 \\
\hline & 10 & 60 & & & $18-$ & 40.0 & 2 \\
\hline \multicolumn{8}{|c|}{$\mathrm{m}^{3}$ 当たりの質量 $\left(\mathrm{Kg} / \mathrm{m}^{3}\right)$} \\
\hline 水 & txi & 細骨材 & & 材 & 濯和 & & \\
\hline 174 & 290 & 752 & 1, & 34 & & & \\
\hline
\end{tabular}

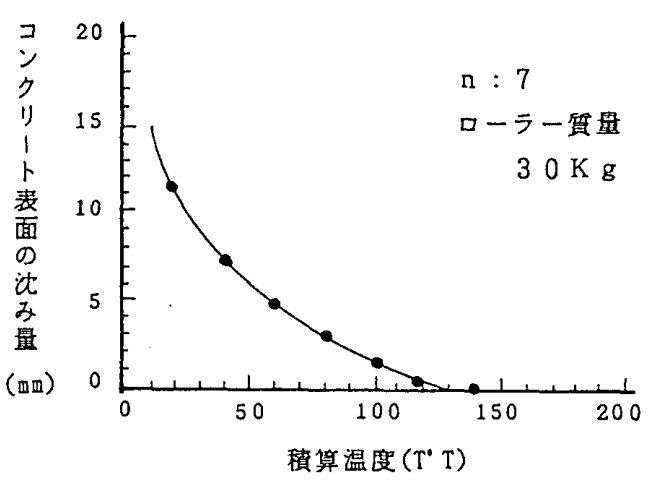

図－5＼cjkstart積算温度とコンクリート表面の沈み量との関係 （ローラー質量 : $30 \mathrm{Kg}$ )

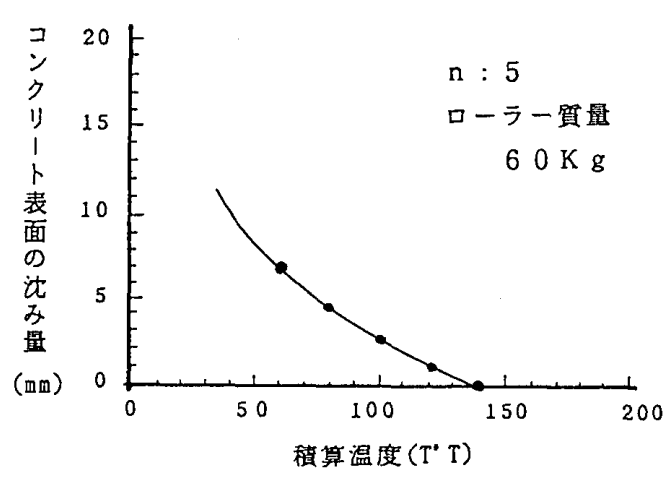

図-6 積算舅度とコンクリート表面の沈み量との関係 （ローラー質量：60 Kg）

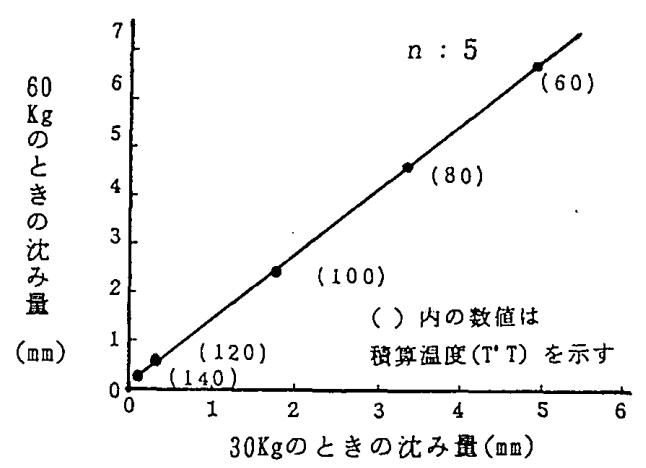

図一7 ローラー質量 $30 \mathrm{Kg}$ と $60 \mathrm{Kg}$ ロコンクリート表 面の沈み量の関係 
ついては次項5.2で検討する。

ローラー質量30Kgと60Kgのときの沈み量の関係を図一 7 に示す。店者には直線関係が認められるが、ローラー 質量が30Kgに対して60Kgの沈み量は、ほぼ1.4倍となっ た。

ここで、ロボットの走行開始時期との関係を見みると、 1 回目のロボットの走行時期は $100 T^{0} T$ 前後であると考 えられ、このときのローラー質量が30Kgの場合では沈み 量が約 $2 \mathrm{~mm}$ 、ローラー質量が60Kgの場合は約 $3 \mathrm{~mm}$ となっ ている。 $100 \mathrm{~T}^{0} \mathrm{~T}$ 時点における $3 \mathrm{~mm}$ 前後の沈み量は、従 来使用されているトロウェルを使用しても羽根（金ごて 相当部分）の回転により沈んだ部分のコンクリート表面 を平坦化と同時に平滑化することは可能である。また、

$100 \mathrm{~T}^{0} \mathrm{~T}$ 時点での接地圧はローラー質量が30Kgの場合で

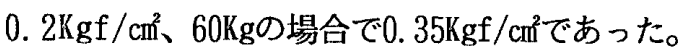

これらの実験結果を、ロボットの移動ローラーの寸法 を設計する際のデータとして使用することとした。

ここでは、コンクリートの硬化度合いの判断指標之し てT T Tを用いたが、コンクリート表層部の性状を把握す るための目安として採用しており、今後、その性状を正 確に捉えるための試験方法やセンサの開発が課題である。 5. 2 ローラーへのセメントペースト付着防止実験 前項で観察されたローラーへのセメントペーストの付 着防止対策を検討することを目的として実験を行った。

（1） 測定項目及び評価方法

コンクリート表面上にローラーやタイヤを走行させた ときのコンクリート表面及びローラーやタイヤ（以下、 総称して走行装置部之呼ぶ）の表面状態について、次に 示す項目について観察した。

a. 走行時のすべり：コンクリート表面で走行装置部 が滑りを生じる現象

b.ノロ押し：コンクリート表面のセメントペースト を走行装置部が押し流す現象

c. ノ口付着 : 走行装置部にコンクリート表面のセメ ントペーストが付着する現象

d. コンクリート表面の剥離 : コンクリートの一部が 走行装置部に付着し、コンクリート表面が剥離す る現象

e. 旋回時の削り : 走行装置部がコンクリート表面上 をこじり、表面に傷をつける現象

f . 洗浄性 : 試験を終了した後の走行装置部の洗浄の 容易さ

以上の項目について、良好の場合は○、やや不良の場 合は $\triangle$ 、不良の場合は×で評洒した。また、上記 $\mathrm{a} \sim \mathrm{f}$ の項目を総合的に評価し、ローラーへのセメントペース 卜の付着防止に適する材料を@、やや適す材料を○、不 適な材料を×で、総合評価した。

\section{（2）実験方法}

供試体は、幅 $60 \mathrm{~cm}$ 、長さ $250 \mathrm{~cm}$ 、厚さ $5 \mathrm{~cm}$ の型枠に、 水セメント比 $56 \%$ 、スランプ $18 \mathrm{~cm} 、 1 \mathrm{~m}^{3}$ 当たりの使用 材料の質量、水 $165 \mathrm{Kg}$ 、セメント $295 \mathrm{Kg}$ 、細骨材 $765 \mathrm{Kg}$ 、 粗骨材 $1,135 \mathrm{Kg}$ 、コンクリート混和剤（AE減水剂） 1.18 Kgのコンクリートを打込んだ。走行装置部はコンクリー 卜打込み後、材歯 3 、3.5、4、4.5時間で、コンク リート表面上を走行させた。コンクリートの温度は 30 $31^{\circ} \mathrm{C}$ であった。ローラーの寸法は、外径 $318.5 \mathrm{~mm}$ 、長さ $350 \mathrm{~mm}$ を使用し、総質量は70Kgとした。

実験に先立ち、走行装置部として使用されるローラー への付着防止刘策として(1)鋼管ローラーの表面を他の材 料で被覆する方法 (2)ローラーの材質を他の材料に変え る方法 (3)被覆材料の表面に凹凸や形状を变化させる方 法及びそれらを組合せる方法などを含めて、表一 3 に示 す17種類の材料を選定した。

一次実験では17種類の走行装置部について実験したが、 その段階で一次実験の評価を行い、ローラー付着防止に 適する材料として ○ 表示が得られた走行装置部につい て二次実験を実施し、最も適玨と思われる走行装置部を 選択することとした。

\section{（3）実験結果及び考察}

表ー3 走行装置部へのセメントペースト付着防止実験 結果

\begin{tabular}{|c|c|c|c|c|c|c|}
\hline \multirow{3}{*}{ 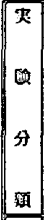 } & \multirow[b]{2}{*}{ D - } & \multirow[b]{2}{*}{$-\infty$} & \multirow[b]{2}{*}{ 标 } & \multicolumn{2}{|c|}{ 画定面目 } & \multirow[t]{2}{*}{13} \\
\hline & & & & \begin{tabular}{|l|l|l|l|l|}
$a$ & $b$ & $c$ \\
\end{tabular} & \begin{tabular}{l|l|l|}
$d$ & $e$ & $f$ \\
\end{tabular} & \\
\hline & 林 证 & 形状 & 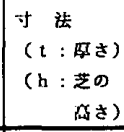 & & 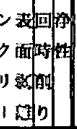 & 鲆 \\
\hline \multirow{7}{*}{-} & 天经コム & 平面 & $t=601$ & $6 \times \times$ & $\times \times 9$ & $x$ \\
\hline & \begin{tabular}{|l|} 
発治ポリエチレン \\
\end{tabular} & 平面 & $t=9 \mathrm{a}$ & $8 \times 9$ & $\triangle$ PA & 0 \\
\hline & 天然イグサ & ししろ简 & & $\mathrm{D} \Delta \Delta$ & $0 \Delta \Delta$ & $\Delta$ \\
\hline & ポリプロビレン & 人坛 & $h=6$ a & pop & o od & (c) \\
\hline & 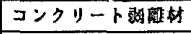 & コーティンタ & & $\Delta \times x$ & $\times \times 0$ & $x$ \\
\hline & オイルレスメタル & オイルレスフォシュ & $(\$ 125 \times 1120)$ & $\Delta \times x$ & $\times \times 9$ & $x$ \\
\hline & 天经コム & Wヘリカル型 & $t=12 \mathrm{at}$ & $8 \times \times 1$ & $\Delta x \mid x$ & $x$ \\
\hline \multirow[t]{4}{*}{2} & 场化ビニル & 四角踓望 & & $0 \times x \times 2$ & $\triangle \times \Delta$ & $x$ \\
\hline & 场化ビニル & 大小中形里 & & $8 \times x=$ & $\Delta \times \Delta$ & $x$ \\
\hline & 天绍コム & 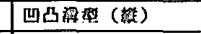 & & $\Delta O \times 1$ & $\Delta \times \Delta$ & $\Delta$ \\
\hline & 天灭销コム & 凹凸酒想（钩） & & $\mathrm{O} \times \times \times 2$ & $\Delta \times \Delta$ & $x$ \\
\hline \multirow[t]{4}{*}{ F } & 米リウレタン系樹脂 & 小六角整 & & $8 \times 1 \times$ & $\Delta|x| x \mid$ & $x$ \\
\hline & 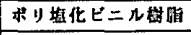 & 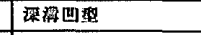 & & popo & $0 \times x \Delta$ & 0 \\
\hline & $\exists ム タ イ+$ & 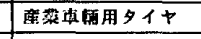 & $(\$ 2700 \pi)$ & pop: & $0 \Delta x$ & 0 \\
\hline & 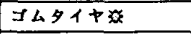 & スクータ一用タイヤ & $(\$ 320 \square \square)$ & oto & $0 \Delta \Delta$ & 0 \\
\hline \multirow[t]{4}{*}{ 안 } & マムタイヤ & トラクタ用タイヤ & $(\$ 342 \square \square)$ & opol & $0 \Delta \Delta$ & 0 \\
\hline & 白成コム & 平面 & & $\Delta \times x$ & $\times 1 \times 0$ & $x$ \\
\hline & ボリプロビレン & 人工芝 （矮消继） & $\mathrm{h}=6 \mathrm{~g}$ II & pose & 000 & (9) \\
\hline & 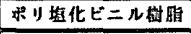 & 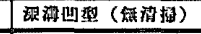 & & opos & $0 \Delta \Delta$ & 0 \\
\hline$=$ & $\pm 10 \geqslant($ GS-3) & 人工芝 (明- 長) & $\mathrm{h}=12 \mathrm{mg}$ & pop & 0 OA & 0 \\
\hline ro & +イロン( $\mathrm{B})$ & 人工芝（明・短） & $h=6$ an & opos & 0 100 & (9) \\
\hline 实 & ナイロン(BS-BP3) & 人工芝（策・辰） & $h=12 a$ & goto & $0 \Delta \Delta$ & 0 \\
\hline 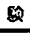 & +1 - & 人工之（菜・短） & $h=5$ aI & goos & 0 oo & (1) \\
\hline
\end{tabular}


一次及び二次実験結果 ${ }^{14)}$ を表ー 3 に示す。

一次実験において、a，走行時すべりは、 4 種類の材 料を除いて良好であった。また、b，ノ口押し、c．ノ 口付着、 d. コンクリート表面の剥離は、各々 8 種類が 良好であり、e. 旋回時削りは 3 種類、f . 洗浄性は 6 種類が良好との評価が得られた。6つの項目がすべて良 好と評価された材料はポリプロピレン製の人工芝だけで あった。また、この人工芝を試験後、清掃せずにそのま ま放置し、再度実験を行った結果においても、すべての 項目を満足した。

二次実験では耐アルカリ性を考虑してナイロン製の人 工芝に変更し、芝の硬さ、長さを組合せて 4 種類の人工 芝について実験を行った。その結果は、表一3の二次実 験結果に示すように芝の硬さ及び芝の長さは洗浄性に影 響を及ぼす以外、その他の項目への影響は少ないことが 判明した。この結果から、芝が短ければ芝の硬さに拘ら ず総合評価で適合すると判断された。

\section{6. ロボットに適合するッールの選定ならびに仕上げ方 法に関する実験}

6. 1 仕上げツールの選定に関する実験

走行を伴いながら作業を進める床直仕上げロボットの 設計においては、移動装置と同時に作業を行うッールの 選定が重要な要素となる。ここでは、床仕上げ作業に適 したロボット用の表面仕上げッールを選定することを目 的として実験を行った。

（1） 実験に用いたシツールの種類

コンクリート床表面仕上げ作業用ツールとして次に示 す 3 種類のツールを用いて実験を行った。

a. ローラー：径 $250 \mathrm{~mm}$ 、長さ $300 \mathrm{~mm}$ （表面：クロー ムメッキ)

b. 金ごて : 幅 $200 \mathrm{~mm}$ 、長さ $300 \mathrm{~mm}$ 、厚さ $1 \mathrm{~mm}$ （ス テンレス製)

c.トロウェル : 径 $600 \mathrm{~mm} 、 3$ 枚羽根、質量 $30 \mathrm{Kg}$ （電 動)

（2）測定項目及び評価方法

コンクリート表面の仕上がり性状の測定項目及び評価 は次に示す方法で行った。

a、ツールがコンクリート表面と接触した部分のコン クリート表面の面積 : 接触面積を比率表示 (\%)

b.コンクリート表面に形成された縞模様の高さ（以 下、波高と乎ぶ）：表面状態を6 段階で評価し、 重み付けを行って点数表示（点）

c. セメントペーストの状態 : 表面状態を 5 段階で評 価し、重み付けを行って点数表示 (点)

d．細・粗骨材の引きずり : ツールにより骨材を引き ずりコンクリート表面に生じる欠樎数を点数表示
(点)

e. その他：上記d。では評価し得ないコンクリート 表面に生じた気泡などの久宿を 1 種類の欠宿につ き 1 点を与え点数表示 (点)

(3) 実験方法

実験に当たり、図ー8に示すレール走行式で所要のツ 一ルが取付けられる実験装置を試作した。供試体の寸法 は、全長は $27 \mathrm{~m}$ 程で、幅は70cm、厚さは $15 \mathrm{~cm}$ とした。 試験体の長さは $150 \mathrm{~cm}$ とし、同一条件になるように連続 してコンクリートを打込んだ。コンクリートの調合は、 水セメント比 $60 \%$ 、スランプ $18 \mathrm{~cm} 、 1 \mathrm{~m}^{3}$ 当たりの使用 材料の質量は、水 $180 \mathrm{Kg}$ 、セメント $300 \mathrm{Kg}$ 、細骨材 906 Kg、粗骨材 $906 \mathrm{Kg} 、$ コンクリート混和剤 (AE減水剤)

1. $48 \mathrm{Kg}$ とした。なお、コンクリート表面性状の観察にお ける有効幅は $50 \mathrm{~cm}$ とした。実験装置の走行速度は 20 〜 $200 \mathrm{~mm} / \mathrm{sec}$ である。

実験は木ごて仕上げならびに最終金ごて仕上げに相当 するタイミングに実施した。仕上げ開始のタイミングは 左官工の判断によった。同時に、 $\mathrm{T}^{0} \mathrm{~T}$ との関連を表示す るため養生温度、コンクリート温度を測定した。

表一 4 に実験条件を示す。

(4) 実験結果及び考察

（a） 木ごて仕上げのタイミングにおける実験結果

実験結果を表－5に示す。同表にはコンクリート表面 とツールの接触比率等と床面の仕上がり性状が良好であ

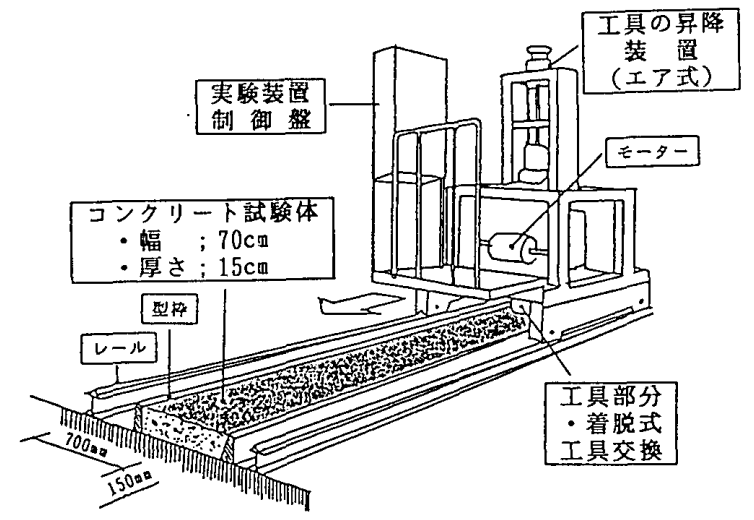

図－8 レール走行式実験装置

\section{表-4 実験条件}

\begin{tabular}{|c|c|c|c|c|c|}
\hline $\begin{array}{l}\text { 仕.ド } \\
\text { タイミ } \\
\text { ンタ }\end{array}$ & $\begin{array}{l}\%-M \\
の \text { 類 }\end{array}$ & $\begin{array}{l}\text { 押 } え \mathbb{E} \\
\left(\mathbb{g} f / \mathbb{d o f}^{\prime}\right)\end{array}$ & $\begin{array}{l}\text { 回枟数 } \\
(\mathrm{rpO})\end{array}$ & $\begin{array}{l}\text { 走行遇度 } \\
(\mathrm{mo} / \mathrm{sec})\end{array}$ & 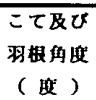 \\
\hline \multirow{3}{*}{$\begin{array}{l}\text { 木こて } \\
\text { 上けP }\end{array}$} & ロ-5- & 1.3 .8 & $30,150,300$ & $30,60,100$ & - \\
\hline & 金こて & 5,10 & $100 \%$ & 30.100 & 5.10 \\
\hline & トロウェル & - & 180 & 30.100 .150 .200 & 8 \\
\hline \multirow{3}{*}{$\begin{array}{l}\hat{1}=\tau \\
\text { 值上 }\end{array}$} & ローラー & $20,45.60,70$ & $30,150,300$ & 30.100 & - \\
\hline & 金こて & $5.10 .25,40$ & $100 \%$ & 10.100 & $5,10,15$ \\
\hline & トロウェル & - & 180 & 150 & 8 \\
\hline
\end{tabular}


つた実験条件を示している。全体的な傾向として、走行 速度は遅く、回転数は早い条件のときが良好な結果を示 した。

（b）金ごて仕上げのタイミングにおける実験結果 実験結果を表一 5 に示す。金ごて仕上げ時はコンクリ

\section{表一 5 実験結果}

\begin{tabular}{|c|c|c|c|c|c|c|c|}
\hline \multirow{2}{*}{$\begin{array}{l}\text { H.上円 } \\
\text { 夕1 } \\
\text { ขタ }\end{array}$} & \multirow{2}{*}{$\begin{array}{l}\text { \%ーnの } \\
\text { 自 }\end{array}$} & \multicolumn{2}{|c|}{ コンクリート真面の锊西 } & \multicolumn{4}{|c|}{ 良好称实经 } \\
\hline & & $\begin{array}{l}\text { \%ールの } \\
\text { 接倘比率 }\end{array}$ & $\begin{array}{l}\text { モの他の箖 } \\
\text { 面蚛地 }\end{array}$ & 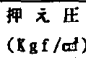 & $\begin{array}{l}\text { 回都 } \\
(\mathrm{rpp})\end{array}$ & 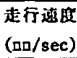 & $\begin{array}{l}\text { こて、羽 } \\
\text { 相角如 }\end{array}$ \\
\hline \multirow[t]{2}{*}{ ネこて } & 口-5- & 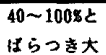 & $\begin{array}{l}\text { 期隹材の露 } \\
\text { 出あり }\end{array}$ & 1 & 300 & 30 & $\rightarrow$ \\
\hline & 佥こ & 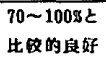 & $\begin{array}{l}\text { 㝵材の引吉 } \\
\text { すりちり }\end{array}$ & 5 & $100 \mathrm{mi}$ & 30 & $5^{\circ}$ \\
\hline 世上げ & $\begin{array}{l}\text { PロDx } \\
n\end{array}$ & $100 x$ C良好 & 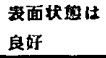 & - & 180 & 150 & $8^{\circ}$ \\
\hline \multirow{2}{*}{ 金こ $\tau$} & ローラー & 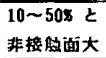 & $\begin{array}{l}\text { ベーストの } \\
\text { 尔山し少 }\end{array}$ & 60 & 300 & 30 & - \\
\hline & 金こて & $\begin{array}{l}\text { 30〜100ðと } \\
\text { ばらつき大 }\end{array}$ & $\begin{array}{l}\text { ベーストの } \\
\text { 辣出し少 }\end{array}$ & 40 & 100 & 30 & $10^{\circ}$ \\
\hline 仕上げ & $\begin{array}{l}\text { raDx } \\
n\end{array}$ & 1008 天良好 & 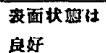 & - & 180 & 150 & $8^{\circ}$ \\
\hline
\end{tabular}

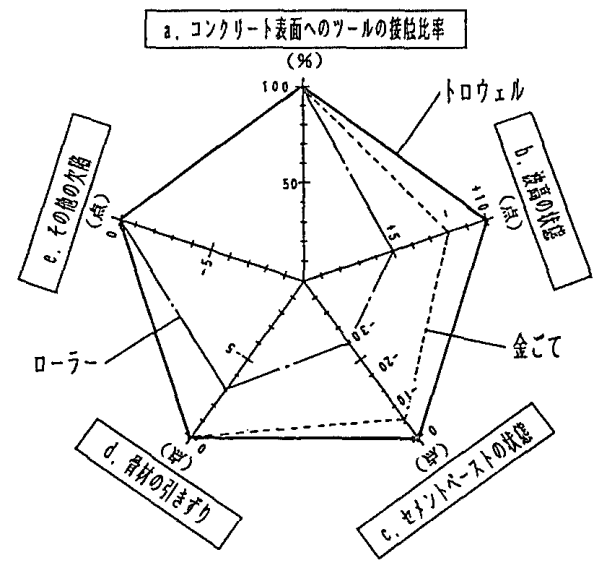

図ー9 ッール別によるコンクリート表面性状の比較 （木ごて仕上げタイミング）

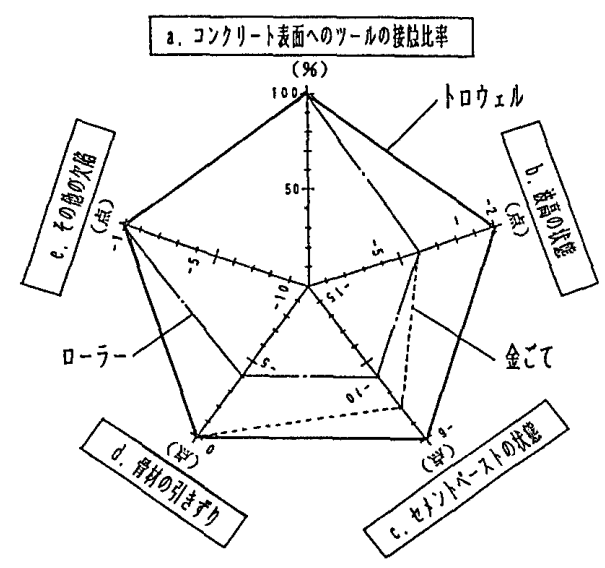

图ー10 ッール別によるコンクリート表面性状の比較 （金ごて仕上げタイミング）
一トか硬化しつつある状態であるため、ローラー及び金 ごての場合のッールの接触此率は木ごて仕上げ時より非 接触部が多くなっており、また、ばらつきも大となった。 しかし、トロウェルを仕上げツールとした場合の実験結 果は、1条件での実験ではあったが、すべての条件を満 足し、コンクリート表面は良好な状態であった。

（c）ツール間の比較

これらの結果から、木ごて仕上げタイミングならびに 金ごて仕上げタイミングについて、それぞれ良好な実験 条件を示したときのコンクリートの表面性状の評価を卜 ロウェルとの比較で絋めて示すと図ー9及び図ー10の とおりである。

ここで、最も重要視しなければならない評価項目はコ ンクリート表面との接触比率である。左官工がこの作業 を行う場合は、非接触面を目で見て判断し、その場所に 何回もこてを当てることにより仕上げを行うことができ るが、ロボットによる作業ではそのような判断機構を現 在の技術では採用することができないため、単純な走行 だけで100\%の接触が可能なツールを選定することが必要 である。以上のような判断から、今回の実験においては、 ロボットに適正な仕上げッールとして、両タイミング共 良好な仕上がり性状が得られたトロウェルを採用するこ ととした。

6. 2 トロウェルによる表面仕上げ作業工程と仕上が りに関する実験

木ごて工程と最終金ごて工程をトロウェルだけで仕上 げるための作業方法と仕上がり性状を検討して、適正な 作業条件を探ることを目的に実験を行った。

（1）実験項目ならびに評価方法

実験項目としては、仕上がり面の表面粗さの測定と官 能検查を行った。コンクリート表面の仕上がり面の表面 粗さの測定には、不陸測定器" を用いた。また、P夕イ ルの下地としての仕上がりの適正度合いについて床仕上 げ材料メーカーの技術者 2名による目視観察ならびにコ ンクリート表面の手触りなどによる官能検査を行った。 試験体は水平に㯰き、屋外で昼間に行った。

（2）実験方法

実験条件としては、表一 6 に示す 4 種類の表面仕上げ 方法を設定した。仕上げタイミングに関しては養生温度 ならびにコンクリート温度を測定し T $\mathrm{T}$ 算定した。実 験に使用した 1 試験体の寸法は、幅3.6m、長さ3m、厚さ $13 \mathrm{~cm} ゙$ あ。実験で用いたトロウェルの仕様は、エンジ ンタイプで羽根回転数 $110 \mathrm{rpm}$ 、羽根外形 $950 \mathrm{~mm}$ 、質量 85 $\mathrm{Kg}$ 、羽根の幅 $160 \mathrm{~mm}$ 、長さ $330 \mathrm{~mm}$ の 4 枚羽根を使用した。 コンクリートの計画調合は、普通コンクリートで、水セ メント比 $49 \%$ 、スランプ12cmで、 $1 \mathrm{~m}^{3}$ 当たりの使用材 料の質量は、水 $153 \mathrm{Kg}$ 、セメント $313 \mathrm{Kg}$ 、細骨材 780 $\mathrm{Kg}$ 、粗骨材 $1,081 \mathrm{Kg} 、$ コンクリート湜和剂（AE減水剂） 
$1.25 \mathrm{Kg}$ とした。

\section{(3) 実”䖽結果と考察}

4 つの異なった方法で仕上げられたコンクリート表面 の仕上がり性状を図-11に示す。仕上げ方法C及び D の表面粗さ（最大高さ）の平均は $0.08 \mathrm{~mm}$ で最も良好な仕 上がりを示した。次いで、仕上げ方法B の表面粗さは $0.14 \mathrm{~mm}$ であり、比較的良好な結果であった。仕上げ方法 A の表面粗さは0.53mmで良好な結果は得られなかった。

この結果を知らせないで、各試験体のコンクリートの 表面性状を休仕上げ材料メ一カ一の技術者によりPタイ ル下地としての官能検查を行った。その結果は、2名の 技術者共、Pタイルを全面的に貼机る下地は C及びDの 仕上げ方法で、B の仕上げ方法は部分的にPタイルが貼 れる、仕上げ方法 A はPタイルの下地として相応しくな いとの判断が下された。この結果から、Pタイルを全面 的に貼れるコンクリートの表面粗さは $0.1 \mathrm{~mm}$ 以下であり、 部分的に貼れるとの判断が下された表面粗さは $0.1 \mathrm{~mm}$ $0.2 \mathrm{~mm}$ 範囲であった。また、0.2mmを越えると P夕イ ルの下地としては相応しくないとの評価が得られた。こ の結果は、4 項で示した表面粗さの実験結果と適合する ものであった。

本実験から、トロウェルだけでコンクリート表面の仕 上げを行うには 2 工程の仕上げだけではPタイルの下地 としては不十分であり、最低でも 3 工程が必要であるこ とが分かった。また、トロウェルによって最終的な仕上 げとすることも可能であることが確認できた。

以上のことから、コンクリート表面仕上げッールとし てトロウェルを使用し、適切なタイミングで 3 工程の仕 上げを行えば、Pタイルの下地として要求されるコンク リート表面粗さを確保できる見通しが得られた。

\section{7. 結 論}

コンクリート床直仕上げロボットの開発をめぐって、 今回行った調查・実験から得られた結論は次のとおりで ある。

1）コンタリート床直仕上げロボットを開発するに当た り、そい開発プロセスならびに検討課題を創案し、開 発の手㞦を提示した。また、ロボットの開発以前に、 作業実態の把握の調查ならびにロボット設計のための 基礎的実験を行うことの重要性を指摘した。

2）左官工による床直仕上げ作業について作業時間を测 定し、作業工程ならびに作業の実態を把握すると共に ロボットにより代替可能な作業範用とその作業分担割 合を推定した。また、ロボットの要求機能の設定に関 し留意すべき知見が得られた。

3）まだ固まらないコンクリート表面上を走行する直仕 上げロボットの移動装置とコンクリート表面の沈み量

\section{表一 6 実験条件（表面仕上げ方法）}

\begin{tabular}{|c|c|c|c|c|c|}
\hline \multicolumn{2}{|r|}{ 作 業 $I . \quad$ 程 （回） } & 1 & 2 & 3 & 4 \\
\hline \multirow{3}{*}{$\begin{array}{l}\text { 实的 } \\
\text { 条件 }\end{array}$} & 目栖糟算温度 $\left(T^{\circ} T\right)$ & 100 & 125 & 150 & 165 \\
\hline & 羽根回転数 ( $\mathrm{r} \mathrm{pm}$ ) & 10 & 60 & 60 & - \\
\hline & 羽㮛解度（度） & 0 & 6 & 10 & - \\
\hline \multirow[t]{4}{*}{ 仕上 } & 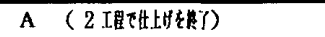 & $T$ & $\rightarrow \mathrm{T}$ & - & - \\
\hline & 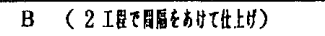 & $\mathrm{T}$ & & $\rightarrow \mathrm{T}$ & - \\
\hline & 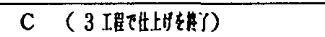 & $T$ & $\rightarrow \mathrm{T}$ & $\rightarrow \mathrm{T}$ & - \\
\hline & 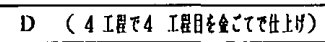 & $T$ & $\rightarrow \mathrm{T}$ & $\rightarrow \mathrm{T}$ & $\rightarrow \mathrm{K}$ \\
\hline
\end{tabular}

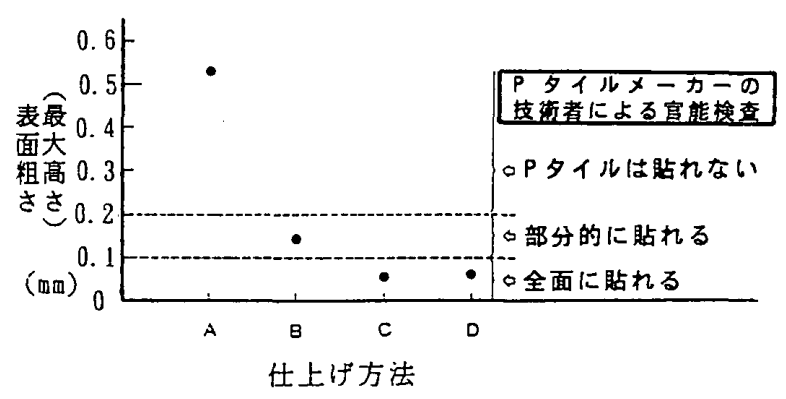

図-11 表面仕上げ方法と表面粗さとの関係

との関係を明らかにして、移動装置の設計上のデータ を得た。また、走行装置部へのコンクリート付着防止 の方法としてナイロン製の人工芝が有効であることを 実証した。

4）キャスター試験ならびに床仕上げ材メーカー技術者 による官能検查の結果から P タイルの下地として要求 されるコンクリート表面の仕上がり精度に関して、表 面粗さ（最大高さ）、段差の目標值を設定し、定量的 な評価の可能性を示した。

5）ロボット用の仕上げ作業ツールとして、トロウェル の有効性を確認すると共に、それを用いた仕上げ方法 について検討を加え、適正なタイミングで 3 回仕上げ ればPタイルの下地として要求されるコンクリート表 面の仕上がり性状が得られることを実証した。 今後の課題として、ロボットの仕上げ開始のタイミン グを的確に把握するためのセンサの開発や作業者の技能 を定量的に捉える手法の開発、仕上がり精度など仕様の 定量化等が挙げられる。

[謝 辞]

本研究に当たり、ご協力を頂いた鹿島建設侏の開発千 ームメンバー関係各位に謝意を表します。 


\section{参蓉文献}

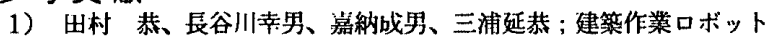
化に関する研究一その 1 建築工事へのロボット導入の勘本的アプ ローチについて一、日本建筑築学会大会学術講演㤦概集 (北海道)、 pp. 485 486、1986.8

2) A. H. Slocum ; Development of Integrated Construction Automation Methodology, International Joint Conference on CAD and Robotics in Architecture and Construction. (Marseille), pp. 450 468. June. 1986

3）菊池、大下、古田、今井；コンクリート床仕上げロボットの開発 と実用化に関する研究、第 1 回建築施工ロボットシンポジウム諭文 集、日本建築学会材禅施工委員会、pp. $1 \sim 6 、 1987.2$

4）梶岡、岡田、高松、小谼; 床仕上げ左官ロボットの開発と適用事 例、第 2 回建筑施工ロボットシンポジウム予稿集、日本建筑学会材 料拖工委員会、pp. $67 \sim 72 、 1988.2$

5）三上責正、荒川球也、小野英哲；コンクリート直仕上げに及ぼす 檄栰こてて仕様およびコンクリート件状の影管の考察、日本建筑学 会構造系詥文報告集、No. 453、pp. 15 26、1993.11

6）難波蓬太郎；動力こてと左官ロボットのための新しい左官用回玆 羽根こてて開発、日本建筑学会大会学街譜演㤦概集 (九州) 、 pp. $901 \sim 902 、 1989.10$

7）新井一彦、山出文三、斎藉 実、坂野弘一；建築用ロボットの開 発プロセスに倸わる考察ーコンクリート床直仕上げロボットの開発
を事例としてー、第 3 回建築施工ロボットシンポジウム予稿集、日 本建筑学会材料施工委員会、pp. 137 142、1989.1

8）新井一彦; 建設ロボットの開発プロセス、施工、No. 271、pp. 57 $\sim 64 、 1988.5$

9）杮朠正義、原出 実、和美広喜、西出光行、荒屋政明夫; 床仕上 け面猜度の测定法、日本建築学会大会学術潇演㤦概集（東海）、pp 229 230、1976. 10

10) C. Brind ; Performance Requirement for Floors Joint [RILEU-ASTH-CIB] Symposium Proceedings, Concept in Buildings, pp. 601 612, 1972.2

11）新井一彦；コンクリート床直仕上げ作業のロボット化（ロボット 阙発のための基磳実験及びロボットシステム）、鹿岛建設技街研究 所年冁、Vol. 34、pp. 101 106、1986. 6

12）笠井芳夫；コンクリートの初期強度、初期福生に関する研究、博 士論文、 1968.10

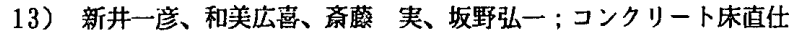
上げロボットの開発、第 7 回コンクリート工学年次譵演会論文集、 日本コンクリート工学協会、pp. 689〜 692、1985.6

14）新井一㢁、山田文三、斎臊 実、坂野弘一、和美広喜; コンクリ 一ト床直仕上げ作業用ロボットの開発とその適用事例、フレッシュ コンクリートの挙動とその施工への応用に関するシンポジウム諭文 集、日本コンクリート工学協会、pp. 169〜 174、1989.4 